\title{
OPTIMASI PROSES DELIGNIFIKASI PELEPAH PISANG UNTUK BAHAN BAKU PEMBUATAN KERTAS SENI
}

\author{
Ika Atsari Dewi ${ }^{1)}$, Azimmatul Ihwah ${ }^{2)}$, Hendrix Yulis Setyawan ${ }^{3)}$, Alfi Ayuning Nur Kurniasari ${ }^{4)}$, dan Afifah Ulfah ${ }^{5)}$ \\ 1,2,3,4,5 Jurusan Teknologi Industri Pertanian, Fakultas Teknologi Pertanian, Universitas Brawijaya \\ 1,2,3,4,5 J1. Veteran No. 1-4 Malang, Telp. 0341-583964 Fax. 0341-568917 \\ E-mail ikaatsaridewi@ub.ac.id ${ }^{1)}$, azimmatul.ihwah@ub.ac.id ${ }^{2)}$, hendrix@ub.ac.id ${ }^{3)}$, alfifiaku@ gmail.com ${ }^{4)}$, \\ afifahulfa1230@gmail.com ${ }^{5}$
}

\begin{abstract}
ABSTRAK
Kertas seni (art paper) adalah produk kertas hasil kerajinan tangan yang bertekstur kasar, serat nampak, dan warna beragam. Kertas seni juga dapat digunakan sebagai salah satu media pemanfaatan limbah pertanian berupa serat bukan kayu seperti pelepah pisang. Pelepah pisang (Musa paradisiaca) adalah bagian dari tanaman pisang yang mengandung selulosa diatas $80 \%$ sehingga dapat dimanfaatkan sebagai bahan baku kertas seni. Pada proses pembuatan kertas dilakukan proses delignifikasi yang bertujuan untuk menghilangkan lignin pada bahan yang dapat menyebabkan kertas bertekstur kaku dan berwarna kecoklatan. Penelitian ini dilakukan dengan menggunakan metode Respon Surface menggunakan software Design Expert 10.0.1 yang bertujuan untuk memperoleh perlakuan optimum proses delignifikasi pelepah pisang. Rancangan percobaan yang digunakan yaitu Rancangan Komposit Terpusat, terdiri dari 2 faktor yaitu konsentrasi $\mathrm{NaOH}$ (\%) dan waktu pemasakan (menit). Kombinasi perlakuan yang dilakukan yaitu untuk konsentrasi $\mathrm{NaOH}$ menggunakan perlakuan $1 \%, 2 \%$ dan 3\%, sedangkan lama waktu pemasakan menggunakan perlakuan selama 90 menit, 120 menit dan 150 menit. Titik optimum hasil delignifikasi pelepah pisang memperoleh hasil perlakuan konsentrasi $\mathrm{NaOH} 3 \%$ dan lama waktu pemasakan 128,413 menit menghasilkan kadar lignin sebesar 2,637\% dan kadar selulosa sebesar $80,713 \%$. Berdasarkan hasil tersebut pelepah pisang dapat dijadikan kertas seni dengan proses delignifikasi untuk memutus rantai ikatan lignin sehingga dapat memperkuat ikatan pulp.
\end{abstract}

Kata Kunci: Pelepah pisang, delignifikasi, konsentrasi NaOH, waktu pemasakan, lignin, selulosa

\section{PENDAhuluan}

Kertas seni (art paper) merupakan salah satu jenis produk kertas hasil kerajinan tangan dengan bahan baku dari kertas bekas sampai pulp limbah pertanian (Sutyasmi, 2012). Kertas seni memiliki tekstur kasar, serat yang terlihat, dan warna beragam. Warna dan tekstur serat kertas seni dipengaruhi oleh bahan baku yang digunakan Kertas seni merupakan salah satu media pemanfaatan limbah pertanian berupa serat bukan kayu, karena tingkat estetika dan keunikan dari kertas seni tergantung dari bahan baku yang digunakan (Muraleedharan and Perumal, 2010). Bahan baku alternatif sebagai pengganti kayu dalam pembuatan kertas seni diantaranya yaitu rumput gajah, sabut kelapa, pinang, klobot, pelepah tanaman salak, bulu ayam dan pelepah pisang. Bahan baku pengganti kayu pada proses pembuatan kertas menjadi hal penting karena semakin hari hutan di Indonesia mengalami pengurangan dan didukung dengan mahalnya harga kayu. Kandungan yang dibutuhkan dalam proses pembuatan kertas yaitu selulosa dalam bentuk serat sehingga sebagian besar tanaman dapat digunakan sebagai bahan baku kertas. Kandungan selulosa yang digunakan acuan dalam pembuatan kertas menurut industri kimia yaitu memiliki kandungan selulosa di atas $80 \%$ (Bahri, 2015). Setiap tanaman memiliki komponen penyusun terbesar yaitu komponen lignoselulosa yang terdiri dari selulosa, hemiselulosa, dan lignin. Pada proses pembuatan kertas komponen tumbuhan yang mempengaruhi yaitu selulosa dan lignin. Hemiselulosa bersama lignin membalut dan menyatukan serat-serat selulosa. Pada proses pembuatan kertas, selulosa memiliki peranan penting karena mengandung serat yang digunakan sebagai bahan baku pembuatan kertas, sehingga untuk memperoleh serat-serat pada selulosa perlu dilakukan proses penghilangan lignin. Kandungan lignin yang tinggi pada kertas akan mengakibatkan kertas berwarna kecoklatan apabila terlalu lama terkena sinar matahari dan membuat tekstur kertas menjadi kaku (Bahri, 2015). Berdasarkan penelitian Saleh et al. (2009), mengenai pembuatan pulp dari sabut kelapa muda, diperoleh kadar selulosa tertinggi sebesar $88,50 \%$ pada kondisi perlakuan konsentrasi $\mathrm{NaOH} 10 \%$, temperatur $100^{\circ} \mathrm{C}$, dan waktu pemasakan 120 menit. Kadar abu paling rendah sebesar $3,28 \%$ diperoleh pada kondisi perlakuan konsentrasi $\mathrm{NaOH} 10 \%$, temperatur $120^{\circ} \mathrm{C}$, dan waktu pemasakan 120 menit. Kadar lignin paling rendah sebesar 11,96\% diperoleh pada kondisi perlakuan konsentrasi $\mathrm{NaOH}$ $10 \%$, temperatur $80^{\circ} \mathrm{C}$, dan waktu pemasakan 90 menit. 
Pelepah pisang (Musa paradisiaca) adalah salah satu bagian dari tanaman pisang yang kurang dimanfaatkan oleh masyarakat. Umumnya pelepah pisang dibuang dan dibakar yang menyenbabkan penumpukan sampah. Pentingnya pengelolaan sampah dilakukan untuk mengurangi jumlah sampah dan mengurangi proses pembakaran sampah. Pengelolaan sampah merupakan salah satu kegiatan yang dilakukan dengan cara pengumpulan, pengankutan, dan pemprosesan daur ulang sampah (Purwandari dkk, 2018). Pelepah pisang biasanya berbentuk kumpulan pelepah yang berdiri tegak. Pohon pisang yang sudah berbuah akan segera mati dan biasanya akan didiamkan hingga menjadi pupuk, sehingga bagian-bagian pohon pisang seperti daun, jantung pisang dan khususnya pelepah pisang kurang dimanfaatkan.

Pelepah pisang memiliki jaringan selular dengan pori-pori yang saling berkaitan sehingga ketika dilakukan proses pengeringan akan menjadi padat. Pelepah pisang merupakan tanaman dengan daya simpan lama, ditemukan di banyak tempat sebagai limbah pertanian, dan biaya yang dikeluarkan cukup rendah dalam perolehan bahan maupun penanganan bahan yang dilakukan. Pelepah pisang memiliki kandungan $\alpha$ selulosa sebesar 83,3\% dan lignin sebesar $2.97 \%$ (Bahri, 2015). Berdasarkan nilai kandungan selulosanya maka pelepah pisang dapat digunakan sebagai alternatif bahan baku kertas pengganti kayu dengan nilai selulosa diatas $80 \%$.

Selulosa adalah polimer dari polisakarida berantai lurus yang tersusun atas glukosa atau unit selobiosa dengan penghubung ikatan $\beta$-1-4-glukan. Didalam selulosa terdapat serat-serat yang digunakan sebagai bahan baku pembuatan kertas. Rantai-rantai selulosa tersusun oleh ikatan hidrogen yang disebut mikrofibril. Mikrofibril selulosa memiliki bentuk amorf dan kristal sekitar 2/3 bagiannya. Bentuk struktur seratnya yang kristal menyebabkan selulosa sulit didegradasi secara enzimatik. Selulosa, hemiselulosa, pektin, dan protein akan membentuk struktur jaringan yang memperkuat dinding sel tanaman (Nikmatin dkk., 2012).

Lignin atau zat kayu adalah suatu komponen ynag mengisi ruang di dalam dinding sel antara selulosa, hemiselulosa, dan pektin. Lignin berfungsi sebagai bagian penting dalam distribusi air di tanaman batang. Komponen polisakarida pada dinding sel tanaman bersifat hidrofilik sehingga permeabel terhadap air, sedangkan lignin lebih hidrofobik. Lignin ada dalam semua tumbuhan vaskular kecuali bryophyta (Setiati dkk., 2016). Menurut unsur-unsur strukturnya lignin dibagi menjadi 2 kelas yaitu lignin guaiasil (terdapat pada kayu lunak hail polimerisasi dari koniferil alkohol) dan lignin guaiasil-siringil (kayu keras hasil kopolimer dari koniferil alkohol dan sinapil alkohol). Lignin bersifat tidak larut dalam pelarut sederhana, namun lignin alkali dan lignin sulfonat larut dalam air, alkali encer, larutan garam dan buffer (Simatupang, 2012). Pada proses pembuatan kertas, lignin merupakan senyawa penghambat ikatan antar serat dan menyebabkan serat menjadi kaku dan serat sukar pecah saat penggilingan yang menyebabkan ikatan antar serat menjadi lebih rendah. Selain itu, kandungan lignin yang tinggi dapat menyebakan kertas berwarna kecoklatan, sehigga lignin pada bahan baku pembuatan kertas harus dihilangkan atau di minimalisir (isolasi) dengan menggunakan proses delignifikasi (Dewi dkk., 2015).

Delignifikasi adalah suatu subproses yang terdapat pada proses pulping yang dilakukan dengan untuk melarutkan lignin yang bertujuan untuk memperoleh hasil serat yang lebih banyak. Pada proses delignifikasi, lignin akan terdegradasi oleh larutan pemasak menjadi molekul yang lebih kecil yang dapat larut dalam lindi hitam. Hal yang perlu diperhatikan yaitu konsentrasi bahan kimia yang digunakan dan waktu pemasakan, semakin besar konsentrasi larutan pemasak dan semakin lama waktu pemasakan, maka lignin yang terhidrolisis akan semakin banyak. Namun konsentrasi larutan pemasak yang terlalu tinggi dan waktu pemasakan yang terlalu lama akan mengakibatkan selulosa terhidrolisis sehingga kualitas pulp yang dihasilkan akan menurun (Dewi dkk., 2015).

Proses perhitungan optimasi dilakukan dengan menggunakan Response Surface Methodology dengan menggunakan 2 respon yaitu nilai uji lignin dan selulosa yang diperoleh dengan menggunakan metode chesson. Metode response surface adalah sekumpulan teknik matematika dan statistika yang digunakan untuk menganalisis permasalahan pengaruh variabel independen dengan variabel respon yang bertujuan untuk mengoptimalisasi respon (Octaviani dkk., 2017). Hasil penelitian ini diharapkan mampu digunakan sebagai alternatif penentuan perlakuan optimal pada proses delignifikasi pelepah pisang sehingga mampu menghasilkan kertas memiliki tekstur baik.

\section{RUANG LINGKUP}

Dalam penelitian ini permasalahan yang dibahas hanya mencakup hal-hal sebagai berikut.:

1. Kandungan lignin yang tinggi pada kertas mengakibatkan kertas kaku dan berwarna kecoklatan apabila terkena cahaya matahari dalam waktu yang lama

2. Limbah pelepah pisang yang melimpah dan kurang memiliki nilai ekonomis tinggi apabila tidak diolah, selain itu sebagai bahan baku pengganti kayu pada proses pembuatan kertas

3. Perlakuan proses delignifikasi pelepah pisang dilakukan dengan menggunakan media pemanas hot plate dan $\mathrm{NaOH}$ sebagai bahan delignifikasi yang dilakukan di Laboratorium Teknologi Agrokimia dan Laboratorium Bioindustri Fakultas Teknologi Pertanian Universitas Brawijaya Malang

4. Penelitian ini hanya dilakukan untuk bahan pelepah pisang (Musa paradisiaca) yang banyak 
dijumpai di daerah Kebonagung, Pakisaji, Malang, Jawa Timur

\section{BAHAN DAN METODE}

Alat dan bahan yang digunakan pada penelitian ini dibagi menjadi 2 proses yaitu proses pembuatan pulp pelepah pisang dan proses pengujian kandungan lignin dan selulosa. Alat yang digunakan dalam proses pembuatan pulp yaitu beaker glass, hot plate, stopwatch, blender, oven, gunting, pisau, gelas ukur, timbangan digital, kain saring, dan pengaduk. Alat yang digunakan untuk uji kandungan lignin dan selulosa yaitu refluks, hot plate, erlenmeyer, timbangan, oven, cawan porselen, desikator, nampan, penjepit, sarung tangan dan muffle furnace.

Bahan yang digunakan pada proses pembuatan pulp yaitu pelepah pisang yang dijumpai di daerah Kebonagung, Pakisaji, Malang, Jawa Timur sebagai bahan utama dan bahan pembantu yaitu natrium hidroksida $(\mathrm{NaOH})$ p.t (pro technis) dengan kemurnian $78 \%$, alumunium foil, aquades $\left(\mathrm{H}_{2} \mathrm{O}\right)$. Bahan yang digunakan untuk proses pengujian kadar lignin dan selulosa yaitu asam sulfat $\left(\mathrm{H}_{2} \mathrm{SO}_{4}\right)$ p.a (pro analyst) dengan kemurnian $98 \%$, aquades $\left(\mathrm{H}_{2} \mathrm{O}\right)$ dan tanah liat.

\subsection{Prosedur Penelitian}

Prosedur optimasi delignifikasi pelepah pisang sebagai berikut.

1. Persiapan bahan penelitian

Pelepah pisang sebagai bahan yang akan dilakukan proses delignifikasi dipotong dengan ukuran $2 \times 2$ untuk mempercepat proses pengeringan.

2. Pengeringan

Proses pengeringan dilakukan dengan diangin anginkan dibawah sinar matahari selama 7 hari. Proses delignifikasi dilakukan dengan larutan $\mathrm{NaOH}$ yang dipanaskan pada suhu $100^{\circ} \mathrm{C}$ selama 90 menit hingga 150 menit sesuai dengan perlakuan yang akan dilakukan. Diagram alir proses delignifikasi pada Gambar 1.

3. Proses pengujian kdar lignin dan selulosa

Hasil pulp kering yang telah diperoleh kemudian dilakukan pengujian kadar lignin dan selulosa menggunakan metode Chesson. Berikut adalah tahapan uji kadar lignin dan selulosa metode Chesson (Mudyantini, 2008):

1) 1 gram sampel kering (berat a), ditambahkan 150 $\mathrm{ml} \mathrm{H}_{2} \mathrm{O}$ atau alkohol-benzene dan direfluk pada suhu $100^{\circ} \mathrm{C}$ dengan water bath selama 1 jam.

2) Hasilnya disaring, residu dicuci dengan air panas $300 \mathrm{ml}$.

3) Residu kemudian dikeringkan dengan oven sampai beratnya konstan dan kemudian ditimbang (berat b).

4) Residu ditambah $150 \mathrm{ml} \mathrm{H}_{2} \mathrm{SO}_{4} 1 \mathrm{~N}$, kemudian direfluk dengan water bath selama 1 jam pada suhu $100^{\circ} \mathrm{C}$.
5) Hasilnya disaring dan dicuci sampai netral $(300 \mathrm{ml}$ $\mathrm{H}_{2} \mathrm{O}$ ) dan residunya dikeringkan hingga beratnya konstan. Berat ditimbang (berat c).

6) Residu kering ditambahkan $100 \mathrm{ml} \mathrm{H} 2 \mathrm{SO} 472 \%$ dan direndam pada suhu kamar selama 4 jam.

7) Ditambahkan $150 \mathrm{ml} \mathrm{H}_{2} \mathrm{SO}_{4} 1 \mathrm{~N}$ dan direfluk pada suhu $100^{\circ} \mathrm{C}$ dengan water bath selama 1 jam pada pendingin balik.

8) Residu disaring dan dicuci dengan $\mathrm{H}_{2} \mathrm{O}$ sampai netral $(400 \mathrm{ml})$.

9) Residu kemudian dipanaskan dengan oven dengan suhu $105^{\circ} \mathrm{C}$ sampai beratnya konstan dan ditimbang (berat d).

10) Selanjutnya residu diabukan dan ditimbang (berat e). Perhitungan kadar selulosa dan kadar lignin menggunakan rumus sebagai berikut (1)

$$
\begin{aligned}
& \text { Kadar Selulosa } \\
& =\frac{\mathrm{c}-\mathrm{d}}{\mathrm{a}} \times 100 \% \\
& \text { Kadar Lignin } \\
& =\frac{\mathrm{d}-\mathrm{e}}{\mathrm{a}} \times 100 \%
\end{aligned}
$$

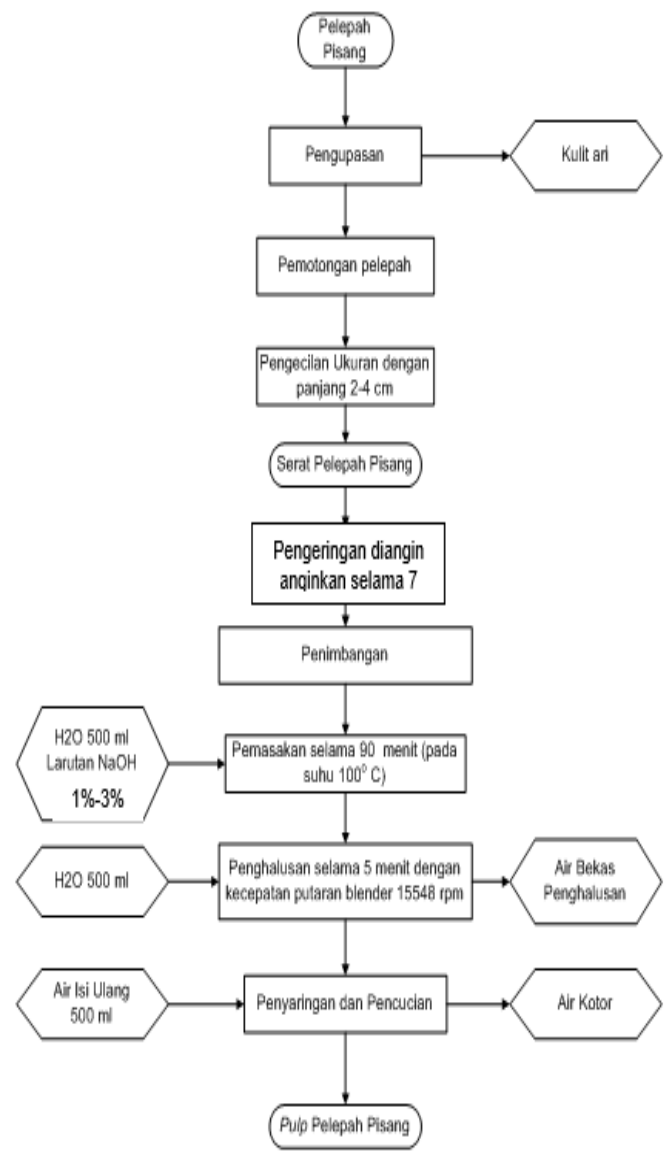

Gambar 1. Diagram Alir Proses Delignifikasi 
Berdasarkan metode tersebut diperoleh nilai kadar lignindan kadar selulosa pada pelepah pisang tanpa perlakuan yang dapat dilihat pada Tabel 1 .

Tabel 1. Kandungan Pelepah pisang

\begin{tabular}{|l|l|}
\hline Kandungan Pelepah Pisang & Nilai \\
\hline Kadar Lignin & $6,4 \%$ \\
\hline Kadar Selulosa & $53,8 \%$ \\
\hline
\end{tabular}

\subsection{Rancangan Percobaan}

Proses optimasi dilakukan dengan menggunakan Metode Respon Permukaan (Response Surface Methodology) dengan menggunakan rancangan percobaan yaitu Rancangan Komposit Terpusat (Central Composit Design) dengan menggunakan 2 faktor perlakuan. Faktor pertama yaitu banyaknya konsentrasi $\mathrm{NaOH}$ yang digunakan dan faktor kedua yaitu lamanya waktu pemasakan. Berdasarkan kedua faktor tersebut, percobaan dilakukan pada titik tengah $(X=0)$. Pada faktor pertama (Konsentrasi $\mathrm{NaOH}$ ) digunakan titik tengah konsentrasi $\mathrm{NaOH}$ sebesar $2 \%\left(\mathrm{X}_{1}=0\right)$, sedangkan faktor kedua (Lama waktu pemasakan) digunakan titik tengah lama waktu pemasakan selama 120 menit $\left(\mathrm{X}_{2}=0\right)$. Pemilihan titik tengah kedua faktor didasarkan pada penelitian (Bahri, 2015) yait kondisi operasi maksimum dari proses pembuatan pulp batang pisang dengan menggunakan konsentrasi $\mathrm{NaOH}$ sebanyak $2 \%$ dan lama waktu pemasakan selama 120 menit. Berdasarka penelitian tersebut menghasilkan kandungan selulosa sebanyak 83,3\% dan kandungan lignin sebanyak 2,97\%. Pada penelitian ini respon yang diuji yaitu kadar lignin $\left(\mathrm{Y}_{1}\right)$ dan kadar selulosa $\left(\mathrm{Y}_{2}\right)$. Kombinasi perlakuan keduanya dapat dilihat pada Tabel 2.

Tabel 2. Kombinasi Perlakuan

\begin{tabular}{|c|c|c|c|c|c|}
\hline \multicolumn{2}{|c|}{ Variabel Kode } & \multicolumn{2}{|c|}{ Variabel Atribut } & \multicolumn{2}{|c|}{ Respon } \\
\hline $\mathrm{X} 1$ & $\mathrm{X} 2$ & $\begin{array}{c}\text { Konsentra } \\
\text { si } \mathrm{NaOH} \\
(\%)\end{array}$ & $\begin{array}{c}\text { Waktu } \\
\text { Pemasaka } \\
\text { n (menit) }\end{array}$ & $\begin{array}{c}\text { Kadar } \\
\text { Ligni } \\
\mathrm{n}\end{array}$ & $\begin{array}{c}\text { Kadar } \\
\text { Selulos } \\
\text { a }\end{array}$ \\
\hline-1 & -1 & 1 & 90 & 5.9 & 62.268 \\
\hline+1 & -1 & 3 & 90 & 4.5 & $\begin{array}{c}72.727 \\
3\end{array}$ \\
\hline-1 & +1 & 1 & 150 & 2.5 & 86.39 \\
\hline+1 & +1 & 3 & 150 & 2.2 & 82.18 \\
\hline-1.414 & 0 & 0.585786 & 120 & 3.5 & 79.37 \\
\hline $\begin{array}{l}+1.41 \\
4\end{array}$ & 0 & 3.41421 & 120 & 1 & $\begin{array}{c}87.562 \\
3\end{array}$ \\
\hline 0 & -1.414 & 2 & 77.5736 & 5.6 & 63.75 \\
\hline 0 & $\begin{array}{l}+1.41 \\
4\end{array}$ & 2 & 162.426 & 5.1 & 63.37 \\
\hline 0 & 0 & 2 & 120 & 4.7 & 72.83 \\
\hline 0 & 0 & 2 & 120 & 4.4 & $\begin{array}{c}72.409 \\
6 \\
\end{array}$ \\
\hline 0 & 0 & 2 & 120 & 4.3 & 72.63 \\
\hline 0 & 0 & 2 & 120 & 4.8 & $\begin{array}{c}73.636 \\
4\end{array}$ \\
\hline $\mathbf{0}$ & $\mathbf{0}$ & 2 & 120 & 4.7 & 71.88 \\
\hline
\end{tabular}

Berdasarkan Tabel 2 maka diperoleh titik komposit terpusat yang dapat dilihat pada Tabel 3 .

Tabel 3. Titik Komposit Terpusat

\begin{tabular}{|c|c|c|c|c|c|}
\hline Faktor & $-\alpha$ & -1 & 0 & 1 & $\alpha$ \\
\hline $\begin{array}{c}\text { Konsentrasi } \\
\text { NaOH (\%) }\end{array}$ & 0.585786 & 1 & 2 & 3 & 3.41421 \\
\hline $\begin{array}{c}\text { Waktu } \\
\begin{array}{c}\text { Pemasakan } \\
\text { (menit) }\end{array}\end{array}$ & 77.5736 & 90 & 120 & 150 & 162.426 \\
\hline
\end{tabular}

Berdasarkan Tabel 3. titik komposit terpusat yang digunakan ada 2 faktor dan 3 level, yaitu faktor konsentrasi $\mathrm{NaOH}$ dan faktor waktu pemasakan dengan 3 level yaitu level -1, 0, dan 1. Rancangan ini diolah dengan menggunakan desain expert yang bertujuan untuk menentukan batasan dalam proses delignifikasi (Rahmah dkk., 2016).

\section{PEMBAHASAN}

Bahan yang tela melalui proses delignifikasi kemudian dikeringkan dan diuji kandungan lignin dan kandungan selulosa menggunakan metode Chesson. Proses pulping yang optimal untuk serat tanaman non kayu menggunakan $\mathrm{NaOH}$ sebagai larutannya. $\mathrm{NaOH}$ dalam pemasakan berfungsi sebagai pemutus ikatan antar serat (selulosa) sehingga dapat mempercepat terbentuknya pulp.

\subsection{Respon Kadar Lignin}

Kandungan lignin pada pelepah pohon pisang yaitu 6,4\%. dapat dilihat pada Tabel 1. Proses delignifikasi bertujuan membantu pemutusan lignin sehingga dapat menghasilkan rendemen yang jauh lebih tinggi, sedangkan menurut Nasution. (2010), delignifikasi merupakan tahap awal yang bertujuan mengurangi kadar lignin didalam bahan berlignoselulosa agar selulosa menjadi lebih mudah diakses. Hasil proses delignifikasi pelepah pisang diperoleh nilai kadar lignin yang dapat dilihat pada Tabel 4. Nilai kadar lignin tertinggi yaitu $5,6 \%$ pada konsentrasi $\mathrm{NaOH} 2 \%$ dengan lama waktu pemasakan 77,57 menit. Kadar lignin setelah proses delignifikasi pelepah pisang yaitu sebesar $1 \%$ pada konsentrasi $\mathrm{NaOH} 3,41 \%$ pada lama pemasakan 120 menit. Nilai tersebut kemudian diolah menggunakan software Design Expert 10.0.1. Pada tabel fit summary diperoleh model matematika yang disarankan pada Model Summary Statistics yaitu Quadratic dengan nilai Adjusted $R$ Squared yaitu 0.7352. Nilai Adjusted $R$ Squared mendekati nilai 1 yaitu $73,52 \%$ menunjukkan model tersebut memiliki keeratan dengan respon. Kesesuaian model matematika tersebut didukung oleh nilai $p$-value pada Lack of Fit Tests pada model quadratic bernilai 0,0047 . Niliai tersebut kurang dari 0,05 yang berarti model matematika quadratic memiliki keseuaian dengan respon. 
Tabel 4. Nilai Kadar Lignin Pulp Pelepah Pisang

\begin{tabular}{|c|c|c|}
\hline $\begin{array}{c}\text { Konsentrasi } \\
\text { NaOH (\%) }\end{array}$ & $\begin{array}{c}\text { Lama Waktu } \\
\text { Pemasakan (menit) }\end{array}$ & $\begin{array}{c}\text { Kadar Lignin } \\
\text { Pulp Pelepah } \\
\text { Pisang (\%) }\end{array}$ \\
\hline 1 & 90 & 5.9 \\
\hline 3 & 90 & 4.5 \\
\hline 1 & 150 & 2.5 \\
\hline 3 & 150 & 2.2 \\
\hline 0.585786 & 120 & 3.5 \\
\hline 3.41421 & 120 & 1 \\
\hline 2 & 77.5736 & 5.6 \\
\hline 2 & 162.426 & 5.1 \\
\hline 2 & 120 & 4.7 \\
\hline 2 & 120 & 4.4 \\
\hline 2 & 120 & 4.3 \\
\hline 2 & 120 & 4.8 \\
\hline 2 & 120 & 4.7 \\
\hline
\end{tabular}

Berdasarkan analisis ragam pada nilai ANOVA menujukkan model yang disarankan yaitu model quadratic dengan nilai $p$-value kurang dari 0,05 yaitu 0,0093 . Pada faktor konsentrasi $\mathrm{NaOH}$ memiliki nilai $p$ value lebih kecil dari 0,05 yaitu 0,0388 maka faktor konsentrasi $\mathrm{NaOH}$ memiliki pengaruh yang signifikan terhadap respon yaitu kadar lignin pulp pelepah pisang. Faktor kedua yaitu lama waktu pemasakan pada proses delignifikasi memiliki nilai $p$-value kurang dari 0,05 yaitu 0,0172 yang menunjukkan faktor lama waktu pemasakan berpengaruh secara signifikan terhadap respon yaitu kadar lignin setelah proses delignifikasi. Diperoleh model matematika quadratic yaitu Y (Kadar lignin $)=12,66744+2,93056 *$ konsentrasi $\mathrm{NaOH}-$ $0,14603 *$ lama waktu pemasakan $+0,0091667 *$ konsentrasi $\mathrm{NaOH} *$ lama waktu pemasakan- $1,17125^{*}$ konsentrasi $\mathrm{NaOH}^{2}+$ $0,000420833 *$ lama waktu pemasakan ${ }^{2}$ dengan $\mathrm{R}^{2}$ $73,52 \%$.

Grafik hubungan faktor konsentrasi $\mathrm{NaOH}$ dan lama waktu pemasakan dengan respon kadar lignin dapat dilihat pada Gambar 2. Pada grafik diperoleh bahwa kedua faktor berpengaruh terhadap respon. Faktor konsentrasi $\mathrm{NaOH}$ terhadap kadar lignin semakin tinggi konsentrasi $\mathrm{NaOH}$ yang ditambahkan makan nilai kadar lignin semakin menurun. Ion $\mathrm{OH}^{-}$pada $\mathrm{NaOH}$ akan memutuskan ikatan dasar pada lignin dan akan larut pada garam fenolat yang terbentuk akibat ikatan $\mathrm{Na}^{+}$dengan senyawa lignin. Lignin yang larut pada larutan $\mathrm{NaOH}$ berwarna hitam yang disebut senyawa lindi hitam. Semakin tinggi konsentrasi $\mathrm{NaOH}$ yang digunakan maka lignin yang terhidrolisis akan semakin besar (Heradewi, 2007). Hal ini dikarenakan adanya penggunaan katalis $\mathrm{NaOH}$ yang berfungsi sebagai pemecah struktur lignoselulosa pada bahan baku pulp. Hal tersebut diakibatkkan oleh masuknya partikel $\mathrm{NaOH}$ kedalam bahan dan memecah struktur lignin (Dewi dkk, 2018).
Faktor lama waktu pemasakan pada Gambar 2 menujukkan grafik penurunan kadar lignin dengan meningkatnya lama waktu proses pemasakan. Semakin lama waktu pemasakan saat proses delignifikasi semakin rendah kadar lignin pada pulp pelepah pisang. Perpindahan panas ini mengakibatkan suhu bahan akan semakin naik jika waktu semakin lama, begitu pula semakin sedikit volume pelarut $\mathrm{NaOH}$ (Maharani dan Khulafaur, 2018).

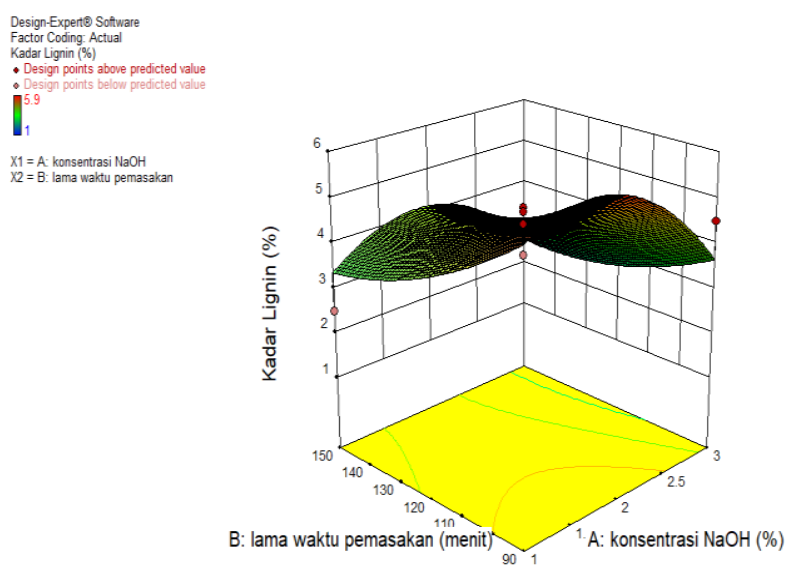

Gambar 2. Grafik Hubungan Faktor dengan Kadar Lignin

Nilai kadar lignin yang diperoleh $1 \%$ hingga 5,9\% mengalami penurunan nilai lignin pada bahan sebesar $6,4 \%$ sebesar $0,5 \%$ hingga $5,4 \%$ lignin. Proses delignifikasi dipengaruhi oleh proses pemasakan pada suhu tinggi yang dapat menghidrolisis polisakarida serat. Semakin tinggi suhu proses pemasakan akan membuat konversi lignin yang terdegradasi semakin besar (Wibisono et al., 2011).

\subsection{Respon Kadar Selulosa}

Kadar selulosa pada pelepah batang pohon pisang sebesar 53,8\% yang disajikan pada Tabel 1. Proses delignifikasi pelepah pohon pisang menujuukan hubungan antara konsentrasi $\mathrm{NaOH}$ dengan waktu pemasakan. Hasil kadar selulosa pulp pelepah pisang dapat dilihat pada Tabel 5. Kadar selulosa tertinggi pada pulp pelepah pohon pisang yaitu 87, $56 \%$ pada perlakuan konsentrasi $\mathrm{NaOH} \quad 3,41 \quad \%$ dan waktu pemasakan 120 menit. Kadar selulosa terkecil diperoleh pada perlakuan penambahan $\mathrm{NaOH} 1 \%$ dengan waktu pemasakan 90 menit sebesar 62,26\% . Data tersebut kemudian diolah untuk memperoleh data optimum menggunakan software Design Expert 10.0.1. Pada tabel fit summary diperoleh model matematika yang disarankan pada Model Summary Statistics yaitu Quadratic dengan nilai Adjusted R Squared yaitu 0.6533. Nilai Adjusted R Squared mendekati nilai 1 yaitu $65,33 \%$ menunjukkan model tersebut memiliki keeratan dengan 
respon. Model tersebut didukung dengan nilai $p$-value pada Lack of Fit Tests yaitu 0,0002.

Tabel 5. Nilai Kadar Selulosa Pulp Pelepah Pisang

\begin{tabular}{|c|c|c|}
\hline $\begin{array}{l}\text { Konsentrasi } \\
\mathrm{NaOH}(\%)\end{array}$ & $\begin{array}{c}\text { Lama Waktu } \\
\text { Pemasakan (menit) }\end{array}$ & $\begin{array}{c}\text { Kadar } \\
\text { Selulosa Pulp } \\
\text { Pelepah } \\
\text { Pisang }(\%) \\
\end{array}$ \\
\hline 1 & 90 & 62.268 \\
\hline 3 & 90 & 72.7273 \\
\hline 1 & 150 & 86.39 \\
\hline 3 & 150 & 82.18 \\
\hline 0.585786 & 120 & 79.37 \\
\hline 3.41421 & 120 & 87.5623 \\
\hline 2 & 77.5736 & 63.75 \\
\hline 2 & 162.426 & 63.37 \\
\hline 2 & 120 & 72.83 \\
\hline 2 & 120 & 72.4096 \\
\hline 2 & 120 & 72.63 \\
\hline 2 & 120 & 73.6364 \\
\hline 2 & 120 & 71.88 \\
\hline
\end{tabular}

Berdasarkan analisis ragam pada tabel ANOVA diketahui faktor konsetrasi $\mathrm{NaOH}$ tidak berpengaruh signifikan terhadap kadar selulosa dengan nilai $p$-value lebih dari 0,05 yaitu 0,2313. Sedangkan, faktor lama waktu pemasakan berpengaruh signifikan terhadap respon kadar selulosa dengan nilai p-value kurang dari 0,05 yaitu 0,0455 . Faktor konsentrasi $\mathrm{NaOH}$ yang tidak berpengaruh signifikan terhadap kadar selulosa menunjukkan bahwa kesalahan galat tidak memengaruhi model matematis. Model matematika yang menunjukkan persamaan garis pada kadar selulosa yaitu Y(kadar selulosa $)=-17.10707-7.05756 *$ konsentrasi $\mathrm{NaOH}$ +1.43922 *lama waktu pemasakan - 0.12224 *konsentrasi $\mathrm{NaOH}^{*}$ lama waktu pemasakan + 5.98904*konsentrasi $\mathrm{NaOH}^{2}-0.00440449$ *lama waktu pemasakan $^{2}$ dengan nilai $\mathrm{R}^{2} 65,33 \%$.

Grafik hubungan konsentrasi $\mathrm{NaOH}$ dengan lama waktu pemasakan terhadap kadar selulosa dapat dilihat pada Gambar 3 menunjukkan grafik hubungan faktor konsentrasi $\mathrm{NaOH}$ terhadap respon yaitu kadar selulosa pada model quadratic tidak signifikan ditunjukkan dengan nilai kadar selulosa pada kenaikan konsentrasi $\mathrm{NaOH}$ mengalami peningkatan kadar selulosa secara fluktuatif. Semakin tinggi konsentrasi $\mathrm{NaOH}$ yang digunakan saat proses delignifikasi kadar selulosa pada pulp pelepah pisang semakin meningkat. $\mathrm{NaOH}$ dapat mengekstraksi hemiselulosa dengan cara memecah struktur amorf pada hemiselulosa. Semakin rendah kadar selulosa menunjukkan bahwa bagian amorf semakin banyak dan bagian berkristal semakin sedikit serta sebaliknya karena kadar selulosa yang rendah dikarenakan banyaknya bagian amorf yang terhidrolisis (Wijana dkk, 2013).

Faktor lama waktu pemasakan pada Gambar 3 menujukkan grafik peningkatan kadar selulosa dengan meningkatnya lama waktu proses pemasakan. Semakin lama waktu pemasakan saat proses delignifikasi semakin tinggi kadar selulosa pada pulp pelepah pisang. Semakin lama waktu pemasakan semakin tinggi suhu dalam larutan dan dapat mempercepat proses hidrolisis alfa seluosa menjadi selulosa dan hemisalulosa.

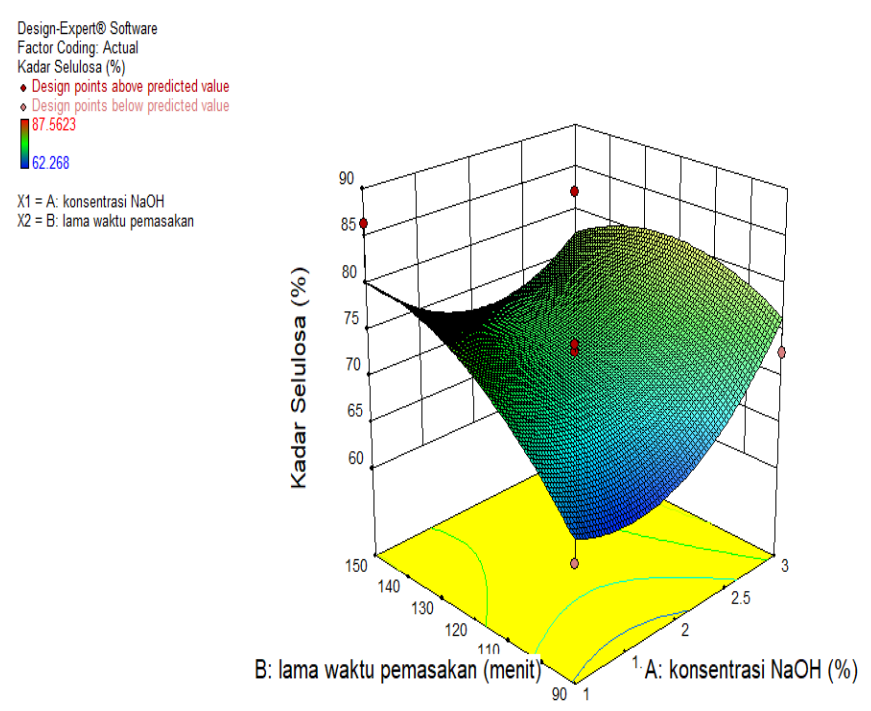

\section{Gambar 3. Grafik Hubungan Faktor dengan Kadar Selulosa}

Nilai kadar selulosa yang diperoleh $62,26 \%$ hingga $87,56 \%$ dipengaruhi oleh proses pemasakan pada suhu tinggi yang dapat menghidrolisis polisakarida serat. Terdapat batasan pada proses hidrolisis yaitu dengan batas maksimal suhu pemasakan $102^{\circ} \mathrm{C}$ dengan tujuan agar selulosa tidak mengalami degradari. Semakin tinggi suhu proses pemasakan akan membuat konversi lignin yang terdegradasi semakin besar dan kadar selulosa dalam pulp juga semakin besar (Wibisono et al., 2011). Nilai kadar selulosa yang diperoleh mendekati nilai kadar selulosa pada pulp industri kertas yaitu kadar selulosa lebih besar dari 80\% (Bahri, 2015). Hal tersebut didukung dengan bentuk fisik pulp pelepah pisang yang memiliki bentuk sama dengan bentuk pulp kertas industri.

\subsection{Hasil Optimasi Terhadap Kadar Lignin dan Kadar Selulosa}

Tujuan penelitian memperoleh nilai optimal terhadap nilai minimasi lignin dan maksimasi kadar selulosa. Faktor konsentrasi yang digunakan pada proses optimasi yaitu $1 \%$ hingga $3 \%$ konsentrasi $\mathrm{NaOH}$ dan lama waktu pemasakan 90 menit hingga 150 menit. Diperoleh hasil pengujian kadar lignin pada nilai $1 \%$ $5,9 \%$ dan kadar selulosa sebesar 62,268\% hingga $87,5623 \%$ yang dapat dilihat pada Tabel 6 . Berdasarkan penelitian ini diperoleh nilai optimum proses delignifikasi pelepah pisang pada konsentrasi $\mathrm{NaOH} 3 \%$ 
dengan lama waktu pemasakan selama 128,413 menit. Berdasarkan nilai optimasi tersebut diperoleh kandungan kadar lignin sebesar 2,637 \% dan kadar selulosa 80,713 $\%$. Batas kendala hasil optimal terhadap respon dapat dilihat pada Tabel 7 .

Tabel 6. Batas Kendala Hasil Solusi Optimal

\begin{tabular}{|c|c|c|c|c|}
\hline Name & Goal & $\begin{array}{c}\text { Lower } \\
\text { Limit }\end{array}$ & $\begin{array}{c}\text { Upper } \\
\text { Limit }\end{array}$ & $\begin{array}{c}\text { Importamc } \\
\boldsymbol{e}\end{array}$ \\
\hline $\begin{array}{c}\text { A:Konsentras } \\
\text { i NaOH }\end{array}$ & In range & 1 & 3 & 3 (Penting) \\
\hline $\begin{array}{c}\text { B: lama } \\
\text { waktu } \\
\text { pemasakan }\end{array}$ & In range & 90 & 150 & 3 (Penting) \\
\hline Kadar lignin & Minimize & 1 & 5.9 & 3 (Penting) \\
\hline $\begin{array}{c}\text { Kadar } \\
\text { selulosa }\end{array}$ & $\begin{array}{c}\text { Maksimiz } \\
e\end{array}$ & $\begin{array}{c}62.26 \\
8\end{array}$ & $\begin{array}{c}87.562 \\
3\end{array}$ & 3 (Penting) \\
\hline
\end{tabular}

Tabel 7. Hasil Solusi Optimal

\begin{tabular}{|l|c|}
\hline Nama & Nilai \\
\hline Konsentrasi $\mathrm{NaOH}$ & $3 \%$ \\
\hline Lama waktu pemasakan & 128,436 menit \\
\hline Kadar Lignin & $2,636 \%$ \\
\hline Kadar Selulosa & $80,712 \%$ \\
\hline Desirability & 0,697 \\
\hline
\end{tabular}

Terdapat nilai Desirability yang merupakan nilai yang mencerminkan bentangan nilai faktor terhadap respon yang menunjukkan derjat ketepatan hasil solusi optimal (Rahma dkk, 2016). Nilai Desirability pada penelitian ini diperoleh nilai 0,697 dapat dilihat pada Gambar 4. Nilai tersebut apabila mendekati satu yang menandakan bahwa nilai masing-masing respon memiliki ketepatan pada hasil solusi optimal (Rasyid et al., 2016;).
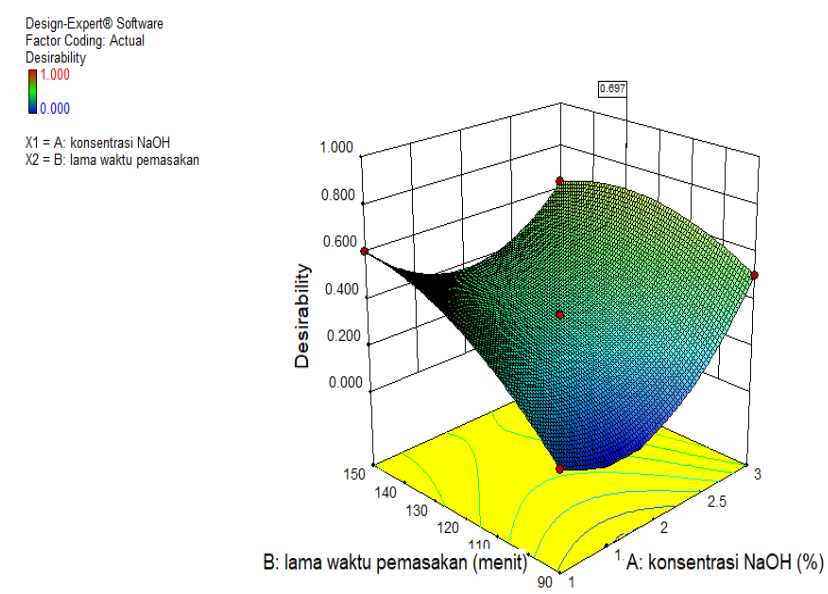

\section{Gambar 4. Grafik Desirability}

Hasil nilai Desirability pada penelitian ini cukup jauh dengan nalai satu disebabkan oleh beberapa faktor yang memengaruhi saat pembuatan sampel pulp dari pelepah pisang. Faktor yang memengaruhi yaitu kondisi bahan pelepah pisang yang digunakan memiliki ketebalan yang berbeda maka kadar air bahan berbeda-beda. Faktor kedua yaitu proses pengeringan dibawah matahari selama 7 hari dengan kondisi cuaca yang tidak menentu. Faktor lainnya yaitu saat proses delignifikasi tidak terdelignifikasi dengan baik yang disebabkan tidak ada proses pengadukan.

\section{KESIMPULAN}

Hasil delignifikasi pelepah pisang diperoleh titik optimum yaitu menggunakan konsentrasi $\mathrm{NaOH} 3 \%$ dengan lama waktu pemasakan selama 128,413 menit. Berdasarkan hasil tersebut diperoleh nilai kadar lignin pelepah pisang setelah delignifikasi yaitu $2,637 \%$ dan kadar selulosa 80,713\%. Berdasarkan nilai tersebut pelepah pisang dapat didijadikan kertas seni dengan proses delignifikasi untuk memutus rantai ikatan lignin sehingga dapat memperkuat ikatan pulp. Kadar selulosa yang diperoleh sesuai dengan nilai selulosa pada pulp kertas industri.

\section{SARAN}

Saran untuk penelitian ini yaitu perlu adanya penelitian lanjut mengenai pengaruh proses pengadukan terhadap proses delignifikasi. Proses pengadukan bagian penting dalam proses delignifikasi untuk pemerataan permukaan bahan saat proses delignifikasi.

\section{DAFTAR PUSTAKA}

Muraleedharan, H., dan Perumal K, 2010, Eco-Friendly Handmade Paper Making. Shri AMM Murugappa Chettiar Research Center: Chennai.

Bahri, S. 2015. Pembuatan Pulp dari Batang Pisang. Jurnal Teknologi Kimia Unimal 4 (2): 36-50

Dewi, I., A., Susinggih, W, Nur, L. R., Erwin S., dan Arie F., M. 2015. Ketahanan Tarik Kertas Seni dari Serat Pelepah Nipah (Nypa fruticans) (Kajian Proporsi Bahan Baku dan Perekat). Prosiding Seminar Agroindustri dan Lokakarya Nasional FKPT-TPI

Dewi, I., A., Azimmatul I., Susinggih W. 2018. Optimization on Pulp Delignification from Nypa Palm (Nypa fruticans) Petioles Fibre of Chemical and Microbiological Methods. IOP Conf. Series: Earth and Environmental Science 187

Heradewi. 2007. Isolasi Lignin dari Lindi Hitam Proses Pemasakan Organosolv SeratTandan Kosong Kelapa Sawit (TKKS). Skripsi.FakultasTeknologiPertanian. IPB. Bogor.

Rasyid, M, F, A, Salim, M, S, Akil, H, M, Ishak, Z, A, M. 2016. Optimization of processing conditions via response surface methodology (RSM) of nonwoven flax fibre reinforced acrodur biocomposites. Procedia Chemistry. 19:469-476

Saleh, A., Pakpahan, M. M. D., dan Angelina, N. 2009. Pengaruh Konsentrasi Pelarut, Temperatur dan 
Waktu Pemasakan Pada Pembuatan Pulp dari Sabut Kelapa Muda. Jurnal Teknik Kimia. 16(3): 35-44.

Sutyasmi, S. 2012. Daur Ulang Limbah Shaving Industri Penyamakan Kulit Untuk Kertas Seni. Majalah Kulit, Karet Dan Plastik Vol.28 No.2 Desember Tahun 2012 : 113-121

Maharani D., M., dan Khulafaur R. 2018. Efek Pretreatment Microwave-NaOH Pada Tepung Gedebog Pisang Kepok terhadap Yield Selulosa. Agritech, Vol 38 No. 2, 133-139

Nasution, Z. A. 2010. Pembuatan dan karakterisasi kertas dari limbah jerami padi untuk tatakan gelas cetak tangan. Jurnal Berita Selulosa. Vol 45 No. 1, 1621

Nikmatin, S., Setyo P., dan Akhirudin M. 2012. Analisis Struktur Selulosa Kulit Rotan Sebagai Filler Bionanokomposit Dengan Difraksi Sinar-X. Jurnal Sains Materi Indonesia Vol. 13, No. 2, Februari 2012, hal : 97 - 102

Setiati, R., Deana W., Septoratno S., Taufan M. 2016. Optimasi Pemisahan Lignin Ampas Tebu Dengan Menggunakan Natrium Hidroksida. Ethos (Jurnal Penelitian dan Pengabdian Masyarakat) Vol 4, No.2: 257-264

Simatupang, H, Andi N., Netti H. 2012. Studi isolasi dan rendemen lignin dari tandan kosong kelapa sawit
(TKKS). Jurnal Teknik Kimia USU, Vol. 1, No. 1. 20-24

Octaviani, M A, Dian R., S., D., Luh J., A. 2017. Optimasi Faktor Yang Berpengaruh Pada Kualitas Lilin Di Ud.X Dengan Metode Response Surface. Jurnal Ilmiah Widya Teknik Volume 16 Nomor 1 29-38

Purwandari D., A., Shahibah Y., dan Nova S., H. 2018. Program Pengabdian Masyarakat: Pengelolaan Hutan Bakau dengan Pendekatan Bank Sampah. Jurnal Nasioan Terindeks Sebatik Vol 22 No.2. 147-152

Wibisono, Ivan, et all. 2011. Pembuatan Pulp Dari Alang-Alang. Jurnal Teknik Kimia Universitas Katolik Widya Mandala Surabaya. Volume 10. No 1. 11-20.

\section{UCAPAN TERIMA KASIH}

Terimakasih kepada Dana Hibah Peneliti Pemula (HPP) Universitas Brawijaya berdasarkan Surat Perjanjian Nomor 696./UN10.C10/PM/2019. serta seluruh pihak yang telah membantu dalam menyelesaikan penelitian ini. 